\title{
Vikten av att reflektera över kön som perspektiv och analyskategori
}

\author{
Inlägg i den debatt som inleddes med Jonny Nilssons artikel
}

\section{Av Lars Hansson, doktorand i historia}

\author{
Länk till presentation av Lars Hansson
}

Jag skulle vilja börja med att uttrycka min glädje över att det förs en engagerad debatt som i detta fallet avseende feminismens ställning i forskningen och dess betydelse för förhållandet mellan forskning och politik. Jag tror att vi genom att föra sådana här interna debatter kan utveckla vårt eget tänkande och genom att gå rakt på sak kan vi minska risken för missförstånd om varandras ståndpunkter.

Jag skulle dock vilja bemöta Jonny Nilsson i det att han påstår att genusperspektivet skulle vara på väg att bli dominerande och därmed vara en påtvingad forskningsinriktning. Istället kan man se att uppmärksammandet av genusperspektiven inneburit att ett tidigare osynligt synsätt fått genomslag. Detta innebär inte att alla måste ha ett viss synsätt på könsrelationerna utan att alla som genomgått forskarutbildning bör vara medvetna om vad olika synsätt på könsförhållanden innebär. Detta innebär då också att man som forskare måste ta ställning till på vilket sätt man själv betraktar dessa förhållanden, på vilket sätt man exempelvis ser på kategorierna manligt och kvinnligt i sin egen forskningsprocess. Tyvärr är det alltför vanligt att forskare har en viss syn på könsförhållandena (som de är medvetna eller omedvetna om) och som ofta kan vara essentialistisk, men som inte redovisas explicit utan som man oftast som läsare själv får söka sig fram till i texten. Vad befrämjandet av genusperspektiv kan medföra är inte ett tvång att omfatta en viss uppfattning - exempelvis har den som är både reaktionär biologist och essentialist lika mycket genusperspektiv som en feminist- bara perspektivet deklareras explicit. Införandet av genusperspektiv innebär enligt detta synsätt att vetenskapen utökats med ännu en dimension. Denna tredje dimension bör vi då alla måste ha med i våra byggen men detta innebär inte att vi bara måste bygga vissa sorters byggnader.

När det gäller genusforskningens koppling till statsfeminism och socialdemokrati så ligger det säkerligen en hel del i kopplingen mellan dessa. Som historisk forskare så bör man vara medveten om att de akademiska forskningen inte utgör någon avskild sfär utan att den i högsta grad är beroende av det omgivande samhället. Tilläggas kan dock att det finns många andra ideologier som utövar mera subtil påverkan på de perspektiv som råder i forskningen. Det ekonomiska systemet vars förtjänster vi alla dagligen njuter - med andra ord kapitalismen - genererar genom sin verksamhet och den hegemoni det utövar en konstant påverkan på allas våra föreställningar om människors mål, relationer och handlingar. Så även andra maktsystem som har stor makt att på olika sätt påverka våra tankesystem. Hela det massmediala systemet formligen vräker ut mängder av bilder dagligen om hur de olika könskategorierna bör vara, se ut osv. Den akademiska forskningen om genusförhållanden utgör ett ganska svagt och relativt sett ganska obetydligt försök att bidra med någon slags diskussion av de könskonstruktioner som slungas ut av de kommersiella medierna. Så visst finns det ett förhållande mellan forskning och politik - det gäller dock att sätta in forskningen i ett större sammanhang. Den akademiska genusforskningen utgör en relativt svag mothegemoni som syftar till att försöka åstadkomma en vetenskaplig diskussion om olika könskonstruktioner, såsom exempelvis de grovt förenklade och människoreducerande könskonstruktioner som skapas av det hegemoniska ekonomiska systemet. Sedd ur detta perspektiv har den akademiska 


$$
\text { Lars Hansson, Vikten av att reflektera över kön som perspektiv och analyskategori }
$$

genusforskningen en viktig roll att fylla genom att i någon mån erbjuda alternativa synsätt och reflektioner. Det kan förvisso betraktas som en politisk funktion.
(C) Lars Hansson 